\title{
An Exegetico-Theological Study of Romans 8:1-8: Toward a Pneumatological-Ecclesiology
}

Isaac Boaheng ${ }^{1}$

${ }^{1}$ Department of Biblical and Religious Studies, University of the Free State, South Africa.

\begin{abstract}
This article focuses on Paul's teachings on how the believer's life in the Spirit contrasts the believer's previous life of sin, with particular reference to Romans 8:18. It first employed the exegetical method - comprising contextual analysis, literary analysis, detailed analysis of lexicology (the meaning of words), morphology (the form of words), grammatical function of words (parts of speech), syntax (the relationships of words) and figures of speech - to explore the text. The next step was a systematic theological formulation of pneumatological-ecclesiology based on the results from the exegetical study of the text. The main argument is that the Spirit applies Christ's salvific work to the believer in a way that does not only put the believer right forensically but also puts him/her right behaviorally. Thus, the believer walking in the Spirit is both justified by the cross and by good deeds performed through the enabling presence of the Spirit. The article contributes to the academic disciplines of systematic theology and biblical studies by exploring what pneumatological-ecclesiology is embedded in the text and applying this formulated theology to the life of the contemporary church, drawing attention to the fact that since the Holy Spirit breathes upon and through the church, the activities of the Spirit in the church should be the plumb line for assessing the nature and conduct of the church. This contribution serves as an effective tool for enhancing ethical and religious renewals in believers in a way that eventually enhances their relationship with God, other humans and the environment.
\end{abstract}

Correspondence:

Isaac Boaheng

Email: revisaacboaheng@gmail. com

\section{Publication History}

Received 23rd August, 2021,

Accepted 6th September, 2021, Published online 14th September, 2021.

\section{Keywords: Death, Flesh, Law, Spirit}

(C) 2021 The Author(s). Published and Maintained by Noyam Publishers.

This is an open access article under the CCBY license (http://creativecommons.org/licenses/by/4.0/).

\section{INTRODUCTION}

The epistle to the Romans is a theologically-loaded book dealing with themes such as justification (3:20-26), righteousness, salvation $(1: 16 ; 5: 9-10 ; 8: 24)$, reconciliation $(5: 10-11)$, expiation $(3: 25)$, redemption $(3: 24)$, sanctification (1:7), transformation (12:2), freedom $(6: 20 ; 7: 3 ; 8: 1-2)$, glorification $(8: 18,21,30)$, the Spirit (ch. 8) and new life in Christ $(6: 4-5,23 ; 8: 29)$, among others. The epistle touches on almost every aspect of the Christian life, especially as related to the Christian gospel. One can therefore not ignore Romans and yet have a full view of the gospel message. ${ }^{1}$ It is in view of this that Romans has been described as "the crown jewel of the epistles." 2

Most New Testament scholars are of the view that Paul wrote the epistle to the Romans. ${ }^{3}$ The book itself states Paul as its author (cf. 1:1) and Tertius as Paul's amanuenses or scribe (see 16:22). It was a common

\footnotetext{
Terry L. Puett, Institute of Biblical Studies Puett's Guide to the Book of Romans (n.p.: Lulu.com, 2012 ), 4.

Puett, Institute of Biblical Studies Puett's Guide to the Book of Romans, 4.

Andreas J. Köstenberger, L. Scott Kellum, and Charles L. Quarles, The Cradle, the Cross, and the Crown: An Introduction to the New Testament (Nashville, TN: B\&H Academic, 2009), 513.
} 
practice in the first-century Greco-Roman world to employ scribes to write letters. It is difficult to determine the actual date for the composition of Romans. Thomas Schreiner's suggestion that Romans was composed between AD 55 and $58^{4}$ seems plausible. Rome was the capital and the biggest city of the Roman Empire with a population of over a million people at the time that the city was at the height of its power. No one knows how the church was formed in Rome. ${ }^{5}$ Paul was not the founder of the Roman church because he had never been to the city of Rome at the time he was writing this letter (see ch. 16). The church might have been established by Jews (living in Rome) who got converted during the visit to Jerusalem - probably during the Day of Pentecost (Acts 2:1-11) and the early stages of the Christian church- and went back to form a local church. Gentiles later joined the church.

Paul most likely wrote the epistle from Corinth close to the end of his third missionary journey (see Acts 18:23-21:15, especially 20:2-3). ${ }^{6}$ This position is supported by the facts that Paul was Gaius' guest in Corinth at the time he was writing Romans (16:3; cf. 1 Cor. 1:14); it is also buttressed by the reference to Erastus, a city treasurer (16:23) and the praise to Phoebe of Cenchrea (the port city of Corinth; 16:1). Some of the reasons for writing this letter include the following. ${ }^{7}$ Paul wrote Romans to resolve tensions between Jewish and Gentile Christians in the Roman church (cf. Rom. 3:20-31; 11:17-32). Paul also used this letter to explain the gospel to the Romans (see 1:16; 3:8 and 9:1-2). The letter also had a missionary purpose evident in Paul's plan to visit the Jerusalem Church and deliver an offering that has been gathered for "the poor among the saints" $(15: 23-24,28 ; 25: 25,26)$.

The eighth chapter of Romans focuses on what benefits a believer will derive from his/her relationship with, Christ - Paul describes this as "life in Christ." Some of these benefits from Christ's work include the believer's freedom from divine condemnation, the indwelling of the Holy Spirit, and freedom from the law of $\sin$ and death. The reader is assured of God's triumphant victory over the weakness of flesh and law. Paul contrasts flesh with spirit, life with death, the law of Spirit with the law of sin and death, being in Christ with not being in Christ, among others. This text states the word pneuma (S/spirit) more than any other chapter in the Bible. "Pneuma" appears in almost every two verses, while the closest competitor, 1 Corinthians 12, states it a little over once every three verses. Paul's focus in this text (Rom. 8) is not so much on the Spirit but on what he (the Spirit) does. He focuses on how the possession of the Holy Spirit should inform human spirituality.

The whole chapter (Rom. 8) emphasizes the theme of assurance and easily divides it into four sections. ${ }^{8}$ In the first section (vv. 1-13) Paul's keyword is "life". He asserts that the "The Spirit of life" (v. 2) gives life to believers both in the present (by redeeming believer from both the penalty [justification] and power [sanctification] of sin) and in the future (through the resurrection of the dead). In verses 14-17, Paul focuses on "the Spirit of adoption" who confers on the believer the status of God's own children and helps them to be aware of that status. The next section compares the future glory of the believer to the present suffering and encourages them not to live as people without hope (vv. 31-39).

The question of how verses 1-13 link up with other parts of the epistle is not easy to answer. However, one can be sure that this section forges a link with Romans 5:12-21. In both 5:12-21 and 8:1-13, Paul not only assures Christians of the reality and finality of life in Christ but also demonstrates how this new life stems from righteousness (cf. 5:17, 18,21;8:10). At the same time, the idea of "newness of life" is anticipated in 7:6b where Paul prepares the reader for what he discusses in chapter 8 . In the previous chapters, Paul has given an account of the state of the person in the bondage of sin and death and he ended this discussion with a personal testimony that God has brought this state to an end. In this chapter, he intends to inform his readers about what God has done to bring this state of helplessness to an end and its consequences in a new way of life.

With this background, the article now proceeds to read the first eight verses of Romans 8 exegetically and theologically.

\footnotetext{
4 Thomas R. Schreiner, "Romans" in Moisés Silva (ed.), Baker Exegetical Commentary on the New Testament (Grand Rapids, MI: Baker Academic, 1998).

5 John Reumann, "Romans" in James D. G. Dunn and J. W. Rogerson (eds.), Eerdmans Commentary on the Bible (Grand Rapids, MI: William B. Eerdmans Publishing Company, 2003), 1277.

6 Reumann, “Romans," 1277.

7 These reasons were gleaned from Mark A. Powell, Introduction to the New Testament: A Historical, Literary, and Theological Survey (Grand Rapids, MI: Baker Academic, 2009), 259.

8 Douglas J. Moo, The Epistle to the Romans: The New International Commentary on the New Testament (Grand Rapids, MI: Wm. B. Eerdmans Publishing Co., 1996), 467.
} 


\section{Close Reading of the Text \\ Deliverance from the Sentence of Sin (v. 1)}

Paul begins this chapter with a short account of God's saving act in Christ, something that he has been constantly referring to and has described earlier (see, for example, 3:21-26). He declares, "There is therefore now no condemnation for those who are in Christ Jesus" (RSV). Paul's use of the combination of ("now therefore") signifies that he is drawing a conclusion on the basis of what he has previously said (especially 5:12-21). ${ }^{9}$ The Greek word nun ("now") also functions as a temporal marker to contrast the life of a person dominated by his human nature with the life of a person controlled by the Spirit. In this sense, "now" serves as an allusion to "the new era of salvation history inaugurated by Christ's death and resurrection (see also 3:21; $5: 9 ; 6: 19,22 ; 7: 6) . " 10$

The word katakrima ("condemnation" or "punishment"1) is a legal term for the process of judgment or its results, including both the sentence and its execution. Throughout the New Testament, this word occurs only here and in 5:16 and 18. Paul's audience would have remained condemned had they remained under the law. The katakrima refers to the divine curse that came upon humanity as a result of the Fall (5:12-21 cf. Gen. $3)$. Douglas J. Moo agrees and further notes that this forensic term is only used thrice in the New Testament $(5: 16 ; 18 ; 8: 1)$; while its verb katakrino occurs sixteen times. ${ }^{12}$ Here, the apostle is not saying that when those who are in Christ sin they will not be responsible for their sins. When they sin, repent and confess they will be forgiven so that there is still $\mathrm{no}^{13}$ basis for them to be condemned. The opposite of condemnation is justification (cf. 5:16; 8:34).

The promise of no condemnation is not a universal one. The absence of condemnation is promised to "those in Christ Jesus." One's relationship with Christ is therefore what frees him/her from condemnation. "To be in Christ" means to be part of the new community of which Christ is both the center and head. ${ }^{14}$ Those who are in Christ have their condemnation (brought by Adam's sins cf. Gen. 3:1-21) reversed. The expression "in Christ Jesus" points back to Romans 6:3-11 where one's union with Christ in his death and resurrection is said to be the pivot about which the believer's death to sin and newness of life in Christ revolves.

Charles Hodge considers this union in three dimensions. ${ }^{15}$ First, the union has the federal dimension just as all humanity was in Adam (1 Cor. 15:22; Rom. 5:12-21). Secondly, the union is in the vital sense as illustrated by the metaphors of the vine (John 15:1-7) or the head and members of the body (1 Cor. 12:27; Eph. 1:23). This union depends on the indwelling of the Holy Spirit (1 Cor. 12:13; 6:15, 19). Thirdly, the union comes by faith (Eph. 3:17; Gal. 3:26, 27). All these dimensions of the union must be present simultaneously in order to be free from condemnation. Clearly, the union with Christ leads to a new way of life, the transformation of character, or the sanctification of the believer. Therefore, those in Christ are justified (or declared righteous) and identified with Christ, and hence have been transferred from death to life so that they now stand in God's grace (5:2) and not under his wrath (1:18) ${ }^{16}$

Most Greek manuscripts (including "representatives of both the Alexandrian and Western type-texts") end verse 1 here. ${ }^{17}$ Others add at the end of this verse the words "who do not walk according to the flesh" while still others add both this phrase and the phrase "who live according to the Spirit." This additional clause seems to have been borrowed from verse $4 .{ }^{18}$ Its originality is therefore in doubt.

\section{Deliverance from the Slavery to Sin (v. 2)}

Verse 2 begins with the particle gar ("for" or "because") to signify that Paul is about telling his readers the reason for which those who are in Christ are beyond condemnation. The sentence serves as the thesis statement

\footnotetext{
9 Moo, The Epistle to the Romans, 471.

10 Moo, The Epistle to the Romans, 472.

11 John A. Witmer, "Romans" in J. F. Walvood and R. B. Zuck (eds.), The Bible Knowledge Commentary: New Testament, pp. 435504 (Colorado Springs: David C. Cook, 1983), 469.

12 Douglas J. Moo, Romans: The NIV Application Commentary (Grand Rapids: Zondervan, 2000), 248.

13 The Greek for "no" (ouden) appears first in the Greek text in the emphatic position.

14 John Knox, "Romans" in G. A. Buttrick et. al. (eds.), The Interpreters Bible, vol. 9 (Nashville: Abingdon Press, 1956$), 506$.

15 Charles Hodge, Romans (Edinburg: The Banner of Truth, 2009), 249-250.

16 Witmer, "Romans," 469.

17 Roger L. Omanson, A Textual Guide to the Greek New Testament (Stuttgart: German Bible Society, 2012 ), 302.

18 Witmer, "Romans," 469.
} 
of the whole of verses 2-30. Paul uses gar to connect "in (through) Christ Jesus" of the present verse with "in Christ Jesus" in verse $1 .{ }^{19}$ The two verses are bound together both by the repetition of the phrase "in Christ Jesus" and the use of gar. Verse 2 provides the basis for Paul's affirmation that "there is no condemnation now for those who live in union with Christ Jesus" (v. 1). Paul's argument is that "condemnation is no longer a reality 'because' ( $g a r$ ) believers are freed from the power of sin." 20 Therefore, the coordinating conjunction gar functions in an explanatory way; there is no condemnation because of what Christ has done in freeing people from the law that condemns them.

Paul describes two diametrically opposing forces: The "law of the Spirit of life" given to the believer offers him/her freedom from the "law of sin and death." "The Spirit of life" refers to the Holy Spirit and not the spirit of the new nature the believer receives (see vv. 6, 10, 11, John 6:63; 1 Cor. 15:45; 2 Cor. 3:6, 17, 18; Gal. 6:8). The reason the Spirit is referred to as "the Spirit of life" is probably that he gives life to believers and will bring human bodies back to life at the resurrection or because he induces the new divine life of the believer in those who obey him. The Holy Spirit is the third person of the Godhead who is responsible for regenerating believers (Tit. 3:5) and imparting them with new life (John 3:5-8). The genitive, "of life," functions as a shorthand way of saying, "the Spirit who gives life," as the "to pneuma zoopoiei" of 2 Corinthians 3:6 illustrates. The reference to the Spirit as "the Spirit of life" is closely linked with chapters 5 and 6 where the Spirit is said to be the one who will apply the resurrection of Christ to believers (see 5:5 and 5:9-11). Again, the Spirit is the one who mediates the newness of life experienced by believers who have identified with Christ's death (cf. 6:4). The Spirit of life is God's antidote to the "living dead" situation in which those taken captive by sin find themselves. This is the second time Paul is mentioning the Holy Spirit since 5:5; Paul mentions him 18 more times through to 8:27.

Another key exegetical question in this verse is: What is "the law of the Spirit of life"? The noun "law" (Greek: nomos) has been used by other New Testament writers in reference to the Pentateuch (see Matt. 5:17, 7:12), the whole of the Old Testament (Matt. 22:36, Luke 10:26), or the commandments of the Mosaic Law (Matt. 5:18). Paul usually thinks of the law in terms of commandments (see Rom. 2:17; 18, 20). The term "nomos" may refer to the Mosaic Law because Paul prefers the use of the term in reference to the Mosaic Law and and there is a similar use in the immediately preceding paragraph (cf. 7:22-23, 25b). However, for the following reasons, it is unlikely that nomos refers to the Mosaic Law in the present context. First, though Paul has stated that the Mosaic Law proves sins $(7: 7,8)$ and produces death $(7: 9-11 ; 2$ Cor. 3:6-7), he also believes the law is holy $(7: 12)$. It will therefore be strange for him to state that the holy law is sin. Second, in the text under consideration, one finds it difficult to conceive of Paul saying that the law in conjunction with the Spirit sets people free from sin and death, because Paul has stated elsewhere that those under the law are under $\sin$. One is therefore inclined to agree with Moo that the first instance of nomos does not refer to the Mosaic Law, as the "immediate context stresses the incapacity of the law to do what v. 2 describes. It was God acting through his Son who accomplished "what the law could not do' (v. 3)." ${ }^{21}$ The noun "nomos" in this text and few other texts (cf. Rom. 3:27; 7:21, 23; 25; 8:2) stands metaphorically for a "principle" or "rule". "The law of the Spirit of life" therefore refers to "regulating and actuating power of the Holy Spirit." 22 In other words, it is the power of the Holy Spirit that works in believers that sets them free from the power of sin by liberating them from the old age and conferring life.

This law sets one free from "the law of sin and death." Paul could have easily said, "the Spirit has set me free from sin and death." He however continues to play on the word "law". Gordon Fee draws attention to the chiastic structure of the "law" starting from 7:13 to illustrate how important it is in Pauline theology:

A $\quad 7: 13$ The (first) Law, Torah, is good, just, holy.

B 7:14-24, 25b But the first Law was "used" by another "law,"

Sin, which in turn led to death.

C 8:2a Enter the third "law," the Spirit of life.

B' $\quad 8: 2 b$ The third "law" sets one free from the second "law," both $\sin$ and death.

\footnotetext{
${ }_{19}$ Moo, The Epistle to the Romans, 473.

20 Thomas R. Schreiner, Romans, (Grand Rapids: Baker Academic, 1998), 399.

${ }^{21}$ Moo, The Epistle to the Romans," 474.

22 John Murray, Epistle to the Romans (Grand Rapids, MI: William B. Eerdmans Publishing Company, 1965 ), 276.
} 
A' 8:3-4 The third "law" fulfills the intent of the First Law, which was incapable of dealing with sin and thus producing righteousness. ${ }^{23}$

The second law is what is now referred to as "the law of sin" and then contrasted with "the Spirit of life." "The law of sin" may refer to "the law which declares sin and death," "the law which shows sin and death," or "the law which causes sin and death." As long as one is under the bond of the law he/she is under sin's control; life in the Spirit breaks this bondage and frees one to live in the newness of life. ${ }^{25}$

There is a textual issue as to whether Paul says "has set us free", "has set you (singular) free," or "has set me free." The first option is rejected by the majority of textual and scholarly evidence. The choice between $m e$ ("me") and se ("you") is however difficult to make. Translations are divided between "you" (NRSV, REB, NJB) and "me" (NIV, RSV, TOB, TEV). The pronoun se has support from both the Alexandrian and Western text-types. It is the more difficult text to read and so it is possible that it was replaced with me which agrees better with Paul's argument in verse 7. At the same time, se may be the case of dittography resulting from the accidental repetition of the final syllable èleutherōsen ("has set free") when the final letter " $n$ " is overlooked. Thus, the former reading may be due to harmonization with verse 7 whilst the latter may be due to dittographical error by copyists. Though the issue is difficult to decide, the writer prefers the former reading, assuming that it is more probable that a scribe would have changed the text from "me" to "you," than the other way around.

\section{Deliverance from the Sickness of Sin (vv. 3-4)}

Paul continues to explain how the freedom mentioned in verse 2 is achieved. In this and the next verse, he returns to the issues raised in 7:5-6, that the Torah's times have ended through Christ and has been replaced by the Spirit. He uses gar in an explanatory manner, linking verses 1 and 2 to verses 3 and 4 . Gar is used epexegetically to introduce a verse showing how believers are freed in Christ. The two verses here are illustrations of the argument that the believer in Christ is beyond condemnation. Schreiner sees a hermeneutical difficulty with this verse because the clause to gar adunaton tou nomou en hō èsthenei dia tēs sarkos, "for that which the law could not do because it was weak through the flesh" does not relate clearly to the rest of the sentence. ${ }^{26}$ There is no scholarly consensus as to whether the expression to adunaton tou nomou refers to the incapability or the impossibility of the law. This expression may be rendered in two different ways depending on the grammatical structure. ${ }^{27}$ Taking the expression to adunaton as the accusative, and supplying the preposition dia, yields the translation, "on account of the impotency of the law." The other option is to take to adunaton as the accusative absolute and translate it as "as to the impotency of the law." Here, Paul declares the impossibility of having freedom over sin through the Mosaic Law. The law has no power to free humans from sin; the Spirit has.

James D. G. Dunn maintains that Paul is attacking the Jewish view that the Torah alone is sufficient for righteousness. ${ }^{28}$ This verse is Paul's most important point about the inability of the law to deliver people from the dominion of sin and death. ${ }^{29}$ However, the law fails in this regard because humans continue to use their own carnal inclinations to regulate their lives; they fail because it is not possible to achieve perfection or freedom from sin through such means. ${ }^{30}$ Thus, the law did not fail because of its content, origins, or nature (cf. 7:12), but because "our lower nature robbed it of all potency" (vv. 3-4 NEB). The law fails to deliver people from sin not because it is inherently weak but because it is weakened by the flesh. The weakness of the flesh refers to moral weakness, not a lack of physical strength. This "weakness" on account of flesh reiterates Paul's contention in the previous chapter concerning human thirst and search for honor, which, in effect, makes

\footnotetext{
${ }^{23}$ Gordon Fee, God's Empowering Presence: The Holy Spirit in the Letters of Paul (Grand Rapids, MI: Baker Academic, 2011), 525.

${ }^{24}$ Fee, God's Empowering Presence, 525.

25 John Calvin, Commentaries on the Epistle of Paul the Apostle to the Romans (Ontario: Devoted Publishing, 2018 ), 210.

26 Schreiner, "Romans," 401.

27 Hodge, Romans, 252-253.

28 James D. G. Dunn, Romans 1-8: World Biblical Commentary (Dallas, TX: Word Press, 1988), 419-420.

29 Moo, The Epistle to the Romans, 478.

${ }^{30}$ Robert Haldane, Romans (Edinburg: The Banner of Truth, 1996), 321.
} 
the law unable to achieve salvation. ${ }^{31}$ Where the law fell short God bridged the gap on the back of Jesus by sending him into the world to be born of a woman under the law. The "sending" formula (indicated by the word pempsas), reflected in Galatians 4:4-5, alludes both to the doctrine of incarnation (John 1:1,14) and the sending of messengers (Isa. 6:8). The main thesis is that "(1) Torah's time is past, because (2) of what Christ has done to (3) sin and the flesh, and (4) its purpose is now fulfilled by the Spirit." 32

The next part of the sentence states that the purpose for which God sent his son was to bring about the fulfillment of the requirements of the law. Paul brings the Torah into the picture and takes readers back to the concerns of 7:5-6, arguing that Christ has ended the era of the reign of the Torah and ushered in the era of the reign of the Spirit. ${ }^{33}$ The Son came in the likeness of sinful human (lit. "likeness of flesh of sin"). Paul's use of the word "likeness" (Greek: homoiōma) is meant to indicate the identity that Christ shared with "sinful flesh." Thus, Paul's point is either that Christ's physical body is just like any other human or that his human nature was exactly the same as that of other humans. The writer argues for the latter position based on Paul's use of "flesh" in the earlier part of this verse. "Flesh" (Greek: sarx) is used to denote the principle of sinfulness (Gal. 5:17; Jude 23), the unregenerate "sinful flesh" (Rom 8:3), and those who live "after the flesh" (Rom. 8:5). ${ }^{34}$ Paul is therefore affirming that even though Christ possessed a human nature that all other humans possess, he remained sinless because he never yielded to the impulses of this fleshly nature. This position agrees with Paul's overall argument in the passage, that is, Christ must fully identify with fallen humanity in order to conquer $\sin$ in the arena where all other humans have been conquered by sin. This motif is also evident and developed further in Paul's Second-Adam Christology (cf. Rom. 5:12-21). Jesus had a human nature exactly like the human nature of other humans but he was without sin. The mode of his incarnation protected and preserved his human nature from being infested with Adam's sin (cf. Luke 1:35).

Paul goes on to indicate that Christ was sent into the world to be a "sin offering." Here, Paul reminisces the Old Testament sacrificial system. The Hebrew word for "sin offering" chattah refers to an offering given to do away with sin or uncleanliness. This offering was required to deal with an unintentional transgression of a prohibition, that either has brought guilt upon the individual or the community (Lev. 15:25-29). It was required from the high priest (vv. 3-12), the entire congregation of Israel (vv. 13-21), a leader (vv. 22-26) and a commoner (vv. 27-35). Paul's metaphorical reference to Christ as a sin offering is meant to affirm that Christ's atonement was meant to deal with the sin of humanity. He took upon himself the sins of all humans and died in place of sinners as if he himself had sinned. Christ used his own blood to cleanse his people in a way comparable to how the high priest of the Old Covenant era used the blood of animals to cleanse his people. On the cross, Christ presented an acceptable sacrifice to God based on which God condemned sin and freed humanity.

In the Greek text, verses 3 and 4 constitute one sentence. Verse 4 begins with a conjunction "in order that" which may be taken either with the force of result or of purpose, the latter being the more probable. The question as to whether Paul's use of the expression "fulfilled in us" is meant to point back to the work of Christ and hence expressing forensic idea (meaning "what the Law required was perfectly fulfilled in Christ's substitutionary death and becomes effective 'in us' as we are 'in him') or whether Paul is anticipating the participial construction and hence pointing toward a more attitudinal aspect of righteousness that the Spirit effects as one walks in him (cf. Gal. 5:13-15) poses exegetical challenges. ${ }^{35}$ In favor of the former position are the arguments that: (i) the word dikaioma ("righteous requirement") is a forensic term related to the practical expressions of the demand of the Law and also that (ii) the expressions "might be fulfilled" and "in us" are meant to highlight what God does on behalf of and in the sinner, rather than what the sinner does; therefore what is fulfilled refers to "what the law could not do" mentioned at the beginning of the sentence. ${ }^{36}$ Against this position is the argument that Paul's concerns show that "fulfillment" has to do with our "walking in keeping with the Spirit." This position does not in any way mean that the fulfillment is not divine activity as

31 Robert Jewett, Romans: Hermeneia-A Critical and Historical Commentary on the Bible (Minneapolis, MN: Fortress Press, 2007), 483.

32 Fee, God's Empowering Presence, 529.

33 Fee, God's Empowering Presence, 528.

34 John A. Motyer, "Flesh," in Evangelical Dictionary of Theology, 2nd ed. Edited by Walter A. Elwell, (Grand Rapids: Baker Academic, 2001), 455-6.

35 Fee, God's Empowering Presence, 534.

36 Fee, God's Empowering Presence, 534-535. 
though one's walking in keeping with the Spirit is a fulfillment of the requirements of the law by one's own effort. Paul's emphasis is on divine initiative and activity in the believer, not by the believer's own strength but by the Spirit's.

According to John Calvin, the fulfillment that Paul has in mind is that which Christ imputes on the believer to declare him/her righteous as if it (the righteousness) were the believer's own or as if the believer had not sinned at all. ${ }^{37}$ This forensic declaration of righteousness based on Christ's atoning work extends "anthropologically to the proclamation of a change in existence" 38 or leads to the "ontological transformation of the "inner being." "39 Therefore, the righteous requirement fulfilled in believers goes beyond a forensic declaration to include a new ontological transformative reality based on one's life in the Spirit, rather than in the flesh. Believers (in their new state) are no longer under the demands of the law; yet, as a result of their transformation through God's own activity, they will fulfill the intention of the law of love (cf. Rom. 13:8), as if they were still under it. ${ }^{40}$ In this case, it is the believer's participation in the new cosmic reality in Christ that sets the stage for God's activity of fulfilling the requirement of the law of love in $\mathrm{him} / \mathrm{her}$.

\section{Mind and Spirit (v. 5)}

Paul uses verses 5-8 to establish the point that the Spirit bestows life but succumbing to the flesh leads to death. With the explanatory gar ("for"), Paul now shifts his emphasis toward cognition, not to treat something new but to elaborate on what has been said earlier. He continues what he began in verse 4 and expands it to give the contrasting focuses of those who live according to the flesh and those who live according to the Spirit (v. 5). Paul's persistent use of the third person plural ("those who") is suggestive that what he says (using the antithesis of flesh and Spirit) is descriptive rather than argumentative or paraenetic. ${ }^{41}$ Paul's primary focus here (unlike in Gal. 5:16-26) is not to caution believers about two different possibilities they face in order to exhort them to live according to the Spirit. Paul's point is that "being in the flesh" is incompatible with "being in the Spirit" or it is impossible for the believer to "be in the flesh." One either lives by flesh or by Spirit. This point reminisces Jesus' assertion that one cannot serve two masters at the same time (Matt. 6:24). The Akan of Ghana express this notion in the proverb, wontumi mfa wo ani mmienu nhwe toa baako mu ("You cannot look into a bottle with two eyes [at the same time]"). Paul's main point is that how one lives is informed by that on which one focuses his/her thoughts. He uses this argument to contrast life controlled by one's own fleshly nature with life controlled by God's Spirit.

The expression "things of the flesh" (NRSV) or "sinful nature" (NIV) derives from the Greek word sarx (flesh) which means the sinful tendencies of human beings. The expression "according to the flesh" continues the same thought of the same expression in verse 4, and the same can be said of the expression "according to the Spirit." Also, the expression "according to the flesh" (vv. 4, 5) has the same effect as the expression "in the flesh" (vv. 8, 9) just as "according to the Spirit" (vv. 4, 5) has the same effect as "in the Spirit" (v. 9). Moo contends that the contrast between "the flesh" and "the Spirit" is a distinction between two realms, the old and the new, and the powers that control these realms in God's salvation history. ${ }^{42}$ These realms also depict two kinds of people, namely those who belong to Christ and those who do not (or the converted and the unconverted). Paul's grouping of humanity into being in the flesh, in Adam, or being in the Spirit, in Christ is a direct contrast to the Greco-Roman anthropological division of humanity into two "ideal types," the foolish and the wise. ${ }^{43}$ Paul's two cosmic realities are incompatible.

\section{Life and Peace (v. 6)}

Paul then proceeds to verse 6 to show that sarx brings death while the Spirit brings life and peace. The flesh and Spirit continue to represent different cosmic realms, the old order and the new order, respectively. The

\footnotetext{
37 John Calvin, Institutes of the Christian Religion, trans. Henry Beveridge (Peabody, MA: Hendrickson, 2008$), 491$.

38 Ernst Käsemann, Commentary on Romans, trans. Geoffrey W. Bromiley (London: SCM, 1980), 29.

39 Peter Dubbelman, “God's New Creation in Romans 8:4," Southeastern Theological Review 9 (1), (2018): 48

40 Dirk J. Venter, "The Requirement of the Law Fulfilled in Romans 8:4," In Die Skriflig 48(1), (2014), 3.

${ }^{41}$ Fee, God's Empowering Presence, 540. See also Moo, "The Epistle to the Romans," 486.

42 Moo, The Epistle to the Romans, 486.

${ }^{43}$ Craig S. Keener, The Mind of the Spirit: Paul's Approach to Transformed Thinking (Grand Rapids: Baker Academic, 2016), $120-123$.
} 
noun phronema ("mind") denotes one's will, reason and affection. The verb "to set one's mind," may mean "to think," "to judge," "to hold an opinion," "to give careful consideration," or "to be intent." Based on contextual considerations, one can agree with Moo that "the mind" encompasses "all the faculties of the soul-reason, understanding, and affection." " 44 The mind of the flesh/Spirit (v. 6) refers to the mid-set or behavior characteristic of those belonging to the flesh/Spirit respectively. In Greek, no verb connects the nouns "flesh" and "death," and so one has to be supplied from the context. Most translators supply "is" and some few others supply "means," or "leads to." Paul uses the middle term "thinking" (phronousin; to be intent on or to set one's mind on) to establish a relationship between one's mode of life (whether in accordance with the flesh or the Spirit) and the respective destinies of death and life (cf. v. 5). ${ }^{45}$

"Death" reigns over all who do not live in Christ (cf. 5:12, 15,21) but life and peace abound for those who are in Christ Jesus. "Death" is used in the broadest sense (both physical and spiritual), to include eschatological condemnation that occurs with individuals who exist in the flesh (see vv. 1-4), but not restricted to that. ${ }^{46}$ The assertion that life is the goal of the Spirit-led life echoes both that which was said in 8:2 where the Spirit is described as the Spirit of life and Paul's association of the Spirit with the verb "to make alive" (in 1 Cor. 15:45 and 2 Cor. 3:6). At the same time, the description of the mindset of the Spirit as life provides a useful link between the Spirit and Paul's discussions on life in Romans 5:9-11 and chapter 6. Both Fee and Moo opine that "life" is the eschatological life inaugurated by Christ whose reconciliatory sacrifice formed the basis for the believer's peace with God. ${ }^{47}$

The reference to eirene ("peace") at this point ties back to Romans 5:1, where "peace" was last used in the epistle. Those in Christ have peace because Christ's reconciliatory work involves God's movement towards the sinner to break the hostility that existed between God and humans due to sin resulting in the establishment of a new relationship characterized by love and friendship. Thus, Paul understands peace as the absence of hostility between God and those who have faith in Christ. This "peace" is that inner "peace with God" effected through justification (see 5:1; 14:17); this peace leads to both physical and spiritual wellbeing. Paul seems to have drawn on Old Testament texts that consider the mind that puts faith and trust in God as experiencing peace (see Isa. 26:2-12; Psa. 78:22). ${ }^{48}$

\section{Sin and Hostility (vv. 7-8)}

Finally, Paul explains why "the mind of the flesh" leads to death (vv. 7-8). He states, "For the mind that is set on the flesh is hostile to God; it does not submit to God's law, indeed it cannot, and those who are in the flesh cannot please God" (NRSV). An unbeliever, that is, the one who sets his/her mind on the flesh cares only for sinful interests and has no regard for God. Such a person is inevitably hostile to God and under divine wrath and judgment. As Moo posits, it is only through Spirit-mindedness that comes through one's relationship with Christ (see vv. 9-10) that one can maintain a relationship with God and thus avoid divine wrath. "Mind on the flesh" leads to death also because "it does not submit to God's law" and cannot do so at any point in time. Consequently, those controlled by the sinful nature cannot in any way please God.

\section{The Spirit and the Ecclesiastical Community}

In this section, the article formulates a pneumatological-ecclesiology based on the above exegetical study. The discussions will cover such areas as the believer's relationship with the Mosaic Law, the renewing power of the Spirit, the believer's use of "spiritual" gifts and the need to be responsible Christians.

\section{The Believer and the Mosaic Law}

The foregoing discourse has established the impossibility of attaining freedom over sin through the obedience to the Mosaic Law. The obvious question that comes to mind is: If the Mosaic Law does not free people from sin, then how relevant is it in the life of the Christian community in the New Covenant era? The author maintains that the Mosaic Law is good and relevant to the Christian community even though it could not solve the

\footnotetext{
${ }_{44}$ Moo, The Epistle to the Romans, 487.

45 Moo, The Epistle to the Romans, 487.

46 Moo, The Epistle to the Romans, 487.

${ }^{47}$ Fee, God's Empowering Presence, 541-42; Moo, The Epistle to the Romans, 488.

48 Keener, The Mind of the Spirit, 138-139.
} 
sin problem. First, the law sets the standard by which God measures Christians to consider their attitude as sinful or not. Secondly, the law moves the sinner to the Savoir. The law prescribes a way of life without giving humans the ability to achieve the prescribed lifestyle. It provides no sacrifice that could actually take away sin and so it could not clear the human conscience of guilt. One's appreciation of the inability to attain righteousness through obedience to the law makes him/her appreciate Christ's salvific work, and accept it through faith. This is what Paul alludes to when he says "... the Law was put in charge to lead us to Christ that we might be justified by faith" (Gal. 3:24). The law achieves its purpose "when one comes to faith in Christ, who is the goal, or fulfillment, of the law (Rom. 10:4)" ${ }^{\prime 49}$ Thirdly, in addition to revealing God's standard and holiness to humans so that we will know how God expects us to live, the law also makes believers aware of the good works God has planned for them (Eph. 2:10). Even though Christians are not under the condemnation of the law (Rom. 6:14, 6; 1 Cor. 9:20; Gal. 2:15-19; 3:25) because of their freedom in Christ (Rom. 6:15), they are required to study and heed the moral demands of the law. ${ }^{50}$ All these invalidate work based salvation theology which some churches preach. The works of the law are good but cannot justify the sinner before God.

\section{Spiritual and Societal Renewal}

The Spirit not only liberates Christians from the works of the flesh but also helps them to overcome their weaknesses. This aspect of the work of the Spirit can be linked to experiential encounters, testimonies and witnesses that underline the different personal and community transformative experiences believers encounter in their religious journey. This dimension of people's encounter with the Spirit is often testified during Sunday worship services, camp meetings, prayer meetings and other occasions. The empowerment of the Spirit not only brings spiritual transformation but also yields social transformation. The new relationship that the Spirit establishes for the believer includes both a lasting relationship with God and with other humans and the environment. As such, the church is expected to transform the society in which it finds itself. The numerous Christian activities such as conferences, revival meetings, prayer meetings and other Christian activities must yield socio-political transformation. ${ }^{51}$ The church must rise up and contribute to the public space, not only through words but also by action. Again, the Christian community must unite in the Spirit and tackle social issues such as ecological problems, poverty, poor leadership and bribery and corruption, injustice, human rights abuse and others. The following quote aptly explains what spirituality is and what it is not: "A churchgoing contractor who executes a government contract poorly is not spiritual. A church leader who evades taxes or imports expired goods is not spiritual; neither is a church member who cheats in an examination. A churchgoing civil servant with a lackadaisical attitude towards work lacks spirituality." ${ }^{52}$ True spirituality must have a positive impact on society.

\section{The Church and Charismata}

Both Käsemann and Dunn agree that a Spirit-led life has charismatic connotations and is associated with endowment with spiritual gifts. ${ }^{53}$ Every believer has some gifts for the edification of the church. It is important however to note that the Spirit is the determiner of these gifts, not the believer (1 Cor. 12:11). Again, none of the gifts is more important than the others (1 Cor. 12:12-30); each gift is given for a purpose that no other gift can perform perfectly. The indwelling of the Spirit and the gifts he bestows on the believer serves to give a foretaste of the eschatological glory that awaits believers. The study requires the church to recognize, nurture and promote the use of the gifts of the Spirit in the context and for the benefit of the Christian community. In their operations, the gifts must complement one another and not contradict. Pentecostals and Charismatics are Christian groups which lay strong emphasis on the role of the Spirit in the ecclesia. There is the need for other churches to take pneumatological-ecclesiology seriously and thus be in a better position to meet the spiritual needs of their members. The pouring of the Spirit (with accompanying gifts and graces) on all fresh is biblical (cf. Joel 2:28-30; Act 2:17-41) and must be given contextual applications wherever the church operate.

\footnotetext{
49 Dan Lioy, The Decalogue in the Sermon on the Mount (New York: Peter Lang Publishing, 2004), 28.

50 Lioy, The Decalogue in the Sermon on the Mount, 28.

${ }^{51}$ Abamfo O. Atiemo, "Crowds that bring no Rains: Religious Revivals and Corruption in Ghana," Trinity Journal of Church and Theology 18(5) (2016):6-23, 7.

52 Isaac Boaheng, Poverty, the Bible and Africa: Contextual Foundations for Helping the Poor (Cumbria: HippoBooks, 2020$), 158$.

53 Käsemann, Commentary on Romans, 176-224; Dunn, Romans 1-8, 422.
} 
It is also important that one does not create confusion in the use of the power and gifts of the Spirit with the Christian community.

\section{Being Responsible Christians}

Finally, Christians must know that the presence of the Spirit in their life does not mean they should expect the Spirit to act take actions which they have been empowered to take. It is wrong, for example, for a Christian student to decide not to learn and then enter examination rooms with the hope that the Spirit-acting through anointed pens and pencils, handkerchiefs and other liturgically anointed objects - will write their exams for them to have excellent results. Those who involve themselves in such practices run the risk of transforming "the Spirit" into a magician. The Spirit empowers, it is the responsibility of the empowered Christian to use that power to take responsible actions.

In the context of the COVID-19 pandemic, for example, it is irresponsible for one not to adhere to the health protocols because of the belief that the indwelling Spirit will prevent that person from contracting the deadly virus. In the view of the author, it is the Holy Spirit who has revealed to scientists that certain protocols can help contain the virus. All true knowledge come from God. Therefore, it is unspiritual and unchristian for anyone to ignore the necessary health protocols; such actions are contrary to God's will. This does not mean that God cannot safe one from the virus if the person does not adhere to the protocols. God is sovereign and so he can do whatever he desires. However, it is tempting and hence a sin to say that because of God's protection one can do whatever he/she likes.

\section{CONCLUSION}

The article has established an unbreakable affinity between Spirit and life on the one hand and flesh and death on the other hand, as well as a link between cognition and behavior in the new cosmic realm, based on Christ's finished work on the Cross. The Spirit applies the new cosmic reality to the believer such that the believer is not only put right forensically but also put right behaviorally. Thus, one's cognitive state as a believer (now empowered by the Spirit) must have both spiritual and social ramifications leading to the transformation of the society to conform to God's will and purpose for the world. Being in Christ under the law of the Spirit, believers are dead to flesh and alive to the Spirit. Believers are no longer living under the law of sin and death but under the law of the Spirit because they are controlled by the Spirit. Formerly they were dead in sin, but after coming to Christ, they are made alive in the Spirit. The unsaved is not able to do good works in the sight of God because he/she does not have the Spirit in him/her to bear fruit. There is the need to suppress the sinful nature to allow the Spirit to take control and then help the believer to bear spiritual fruit. The article is relevant for enhancing ethical and religious renewals in believers in a way that eventually leads to improved human-divine, human-human and human-environment relationships.

\section{ABOUT AUTHOR}

Isaac Boaheng is an ordained minister of the Methodist Church Ghana, a Translator with the Bible Society of Ghana, and a part-time lecturer at the Christian Service University College, Ghana. Boaheng holds a Master of Divinity degree from the Trinity Theological Seminary, Accra, Ghana, he has recently completed a PhD program (awaiting graduation) at the University of the Free State, South Africa, where he also serves as a Research Fellow. Boaheng has over forty publications in Translation Studies, Systematic Theology, Biblical Studies, Methodist Studies and African Christianity, among others.

\section{BIBLIOGRAPHY}

Atiemo, Abamfo O. "Crowds that bring no Rains: Religious Revivals and Corruption in Ghana." Trinity Journal of Church and Theology 18(5) (2016):6-23.

Boaheng, Isaac. Poverty, the Bible and Africa: Contextual Foundations for Helping the Poor. Cumbria: HippoBooks, 2020.

Calvin, John. Commentaries on the Epistle of Paul the Apostle to the Romans. Ontario: Devoted Publishing, 2018. 
Calvin, John. Institutes of the Christian Religion, trans. Henry Beveridge. Peabody, MA: Hendrickson, 2008.

Dubbelman, Peter. "God's New Creation in Romans 8:4." Southeastern Theological Review 9 (1), (2018).

Dunn, James D. G. Romans 1-8: World Biblical Commentary. Dallas, TX: Word Press, 1988.

Fee, Gordon. God's Empowering Presence: The Holy Spirit in the Letters of Paul. Grand Rapids, MI: Baker Academic, 2011.

Haldane, Robert. Romans. Edinburg: The Banner of Truth, 1996.

Hodge, Charles. Romans. Edinburg: The Banner of Truth, 2009.

Jewett, Robert. Romans: Hermeneia-A Critical and Historical Commentary on the Bible. Minneapolis, MN: Fortress Press, 2007.

Käsemann, Ernst. Commentary on Romans, trans. Geoffrey W. Bromiley. London: SCM, 1980.

Keener, Craig S. The Mind of the Spirit: Paul's Approach to Transformed Thinking. Grand Rapids:Baker Academic, 2016.

Knox, John. "Romans" in G. A. Buttrick et. al. (eds.), The Interpreters Bible, vol. 9. Nashville: Abingdon Press, 1956.

Köstenberger, Andreas J., Kellum, L. Scott and Quarles, Charles L. The Cradle, the Cross, and the Crown: An Introduction to the New Testament. Nashville, TN: B\&H Academic, 2009.

Lioy, Dan. The Decalogue in the Sermon on the Mount. New York: Peter Lang Publishing, 2004.

Moo, Douglas J. Romans: The NIV Application Commentary. Grand Rapids: Zondervan, 2000.

Moo, Douglas J. The Epistle to the Romans: The New International Commentary on the New Testament. Grand Rapids, MI: Wm. B. Eerdmans Publishing Co., 1996.

Motyer, John A. "Flesh," in Evangelical Dictionary of Theology, 2nd ed. Edited by Walter A. Elwell. Grand Rapids: Baker Academic, 2001.

Murray, John. Epistle to the Romans. Grand Rapids, MI: William B. Eerdmans Publishing Company, 1965. Omanson, Roger L. A Textual Guide to the Greek New Testament. Stuttgart: German Bible Society, 2012.

Powell, Mark A. Introduction to the New Testament: A Historical, Literary, and Theological Survey. Grand Rapids, MI: Baker Academic, 2009.

Puett, Terry L. Institute of Biblical Studies Puett's Guide to the Book of Romans. n.p.: Lulu.com, 2012.

Reumann, John. "Romans" in J. D. G. Dunn and J. W. Rogerson (eds.), Eerdmans Commentary on the Bible. Grand Rapids, MI: William B. Eerdmans Publishing Company, 2003.

Schreiner, Thomas R. "Romans" in Moisés Silva (ed.), Baker Exegetical Commentary on the New Testament. Grand Rapids, MI: Baker Academic, 1998.

Schreiner, Thomas R. Romans. Grand Rapids: Baker Academic, 1998.

Venter, Dirk J. "The Requirement of the Law Fulfilled in Romans 8:4.” In Die Skriflig 48(1), (2014).

Witmer, John A. Romans. In Walvood, JF and Zuck, RB (eds.). The Bible Knowledge Commentary: New Testament, pp. 435-504. Colorado Springs: David C. Cook, 1983. 